Uniwersytet im. A. Mickiewicza, Poznań

\title{
Budowa podstaw systemu partyjnego współczesnej Rosji
}

\section{Początki demokracji a system partyjny}

System partyjny w Rosji jest dopiero kształtowany. Pierwsze kilkanaś-

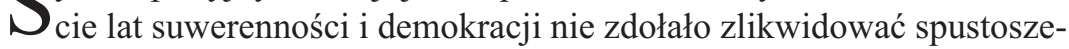
nia w systemie politycznym i kulturze politycznej społeczeństwa, jakie spowodowały dziesięciolecia systemu totalitarnego.

Na ukształtowanie się systemu partyjnego mają wpływ bardzo różne czynniki. Za R. Herbutem możemy wskazać na dwie podstawowe grupy determinant, które łączy fakt, iż tworzą szeroko rozumiane otoczenie systemu partyjnego ${ }^{1}$. Są to, po pierwsze, determinanty związane z tzw. społecznym otoczeniem systemu partyjnego. Wśród nich szczególną rolę odgrywa struktura społeczeństwa i zmiany zachodzące w jej obrębie oraz zachowania wyborcze dominujące $\mathrm{w}$ ramach określonego systemu wyborczego. W przypadku Rosji czynniki te miały zgoła inny wpływ na proces instytucjonalizacji partii politycznych niż w państwach o ukształtowanej już demokracji. Nie mniej jednak wspomniane uwarunkowania wywarły wpływ także na budowę systemu partyjnego w Federacji Rosyjskiej. Szczególną rolę odgrywa tu proces tworzenia się dopiero nowych podziałów społecznych. Nie zostały one jeszcze zamknięte. Tym samym nie ustabilizował się system partyjny, który powinien odzwierciedlać strukturę społeczeństwa. Wciąż trwają próby tworzenia partii politycznych, które stanowiłyby polityczną reprezentację większych grup. Proces ten, jak na razie, jest wciąż daleki od zakończenia.

Znacznie korzystniej wygląda sprawa z zależnością systemu partyjnego Rosji od systemu wyborczego. Zasady prawa wyborczego są w zasadzie stałe i nie ulegają koniunkturalnym zmianom. Stąd też można postawić

\footnotetext{
1 R. Herbut, Systemy partyjne w Europie Zachodniej-ciagłość i zmiana. Studium porównawcze, Wrocław 1996, s. 76.
} 
tezę, iż prawo wyborcze powinno wywierać stabilizujący wpływ na rosyjski system partyjny. Tak się jednak nie stało. Przyczyn tego stanu rzeczy jest wiele. Do najważniejszych należy zaliczyć wielość konfliktów społecznych, brak zaplecza politycznego i rozbudowanych struktur partyjnych w terenie oraz niechęć liderów największych ugrupowań politycznych do zawierania chociażby taktycznych sojuszy. W efekcie przy bardzo ważnych kampaniach politycznych, jakimi są wybory prezydenckie, decydowały o zwycięstwie nie partie polityczne, a struktury administracyjne państwa, które stanowiły zaplecze organizacyjne konkretnego kandydata. Wykorzystywano więc aparat państwowy do prywatnej walki politycznej kandydata na urząd prezydenta. W takiej sytuacji nie może dziwić fakt, iż partie polityczne, skoro nie są skuteczne, nie cieszą się tak wielkim zainteresowaniem jak w państwach, gdzie procedury demokratyczne są bardziej zakorzenione.

Druga grupa determinant wywierających wpływ na system partyjny jest związana z tzw. instytucjonalnym otoczeniem systemu partyjnego. W tym przypadku chodzi o reżim polityczny jako układ reguł gry decydujący nie tylko o charakterze i przebiegu procesu rywalizacji, ale również określający sposób powiązania centrów decyzyjnych $\mathrm{z}$ otoczeniem społecznym. Wiąże się z tym konieczność uwzględnienia $\mathrm{w}$ analizie systemu partyjnego, zarówno formalnych, jak i nieformalnych zasad regulujących wzajemne powiązania między rządzącymi a rządzonymi oraz sposób dystrybucji uprawnień politycznych w obrębie centrum dyspozycyjnego. Zwłaszcza dwa elementy reżimu politycznego wydają się istotne $\mathrm{w}$ analizie procesu tworzenia się i zmiany systemu partyjnego, a mianowicie charakter systemu wyborczego oraz typ reżimu politycznego ${ }^{2}$. O tym pierwszym wspomniano już wyżej. Jeżeli chodzi o drugi ze wskazanych elementów, to jego najważniejszym wyrazem, w przypadku Rosji, jest dominująca pozycja ustrojowa Prezydenta Federacji Rosyjskiej oraz bardzo zatomizowany politycznie parlament, co jeszcze bardziej wzmacnia władzę wykonawczą. Sposób sprawowania władzy oparty jest na silnej jej centralizacji, co nie sprzyja rozwojowi partii politycznych. Żaden z dotychczasowych Prezydentów Federacji Rosyjskiej nie posiadał przecież własnej partii, która stanowiłaby jego opokę i zaplecze polityczne. Udawało się im zdobyć władzę i skutecznie rządzić bez takiej organizacji politycznej.

2 Ibidem, s. 77. 
Ważnym elementem wpływającym na kształt systemu partyjnego jest realizowana przez poszczególne partie strategia polityczna. Najogólniej rzecz ujmując dotyczy ona kwestii programowych oraz zawierania sojuszy. W tym pierwszym przypadku chodzi o adoptowanie się partii do zmieniających się warunków zewnętrznych, czyli otoczenia społecznego. Wraz z ewolucją poglądów i nastrojów społecznych modyfikacji ulegają założenia programowe partii. Dostosowuje ona swoje tezy programowe do oczekiwań społeczeństwa a przynajmniej swego elektoratu. Tym samym odpowiada na zapotrzebowanie społeczne i występuje z określoną ofertą do społeczeństwa. Jest to jednocześnie sygnał kierowany do pozostałych ugrupowań politycznych. Stanowi on wstępną ofertę programową dla ewentualnych sojuszy i porozumień. Mogą one zostać zawarte już na etapie walki wyborczej, albo zostaną skonsumowane dopiero po wyborach, gdy rozpocznie się proces tworzenia koalicji rządzącej.

W Rosji opisane powyżej procesy przebiegają w specyficzny sposób. Po pierwsze w większości przypadków partie polityczne nie uzyskały jeszcze takiego stopnia wewnętrznej spójności organizacyjnej i programowej, która pozwoliłaby na precyzyjne i trwałe określenie ich charakteru ideowo-programowego. Wiele spośród nich ma nadal charakter efemeryczny zarówno w sensie programowym, jak i organizacyjnym. Niektóre są tworzone na czas tylko jednej kampanii wyborczej, a następnie znikają ze sceny politycznej.

Na bardzo rozciagnięty w czasie proces kształtowania się systemu partyjnego w Federacji Rosyjskiej bez wątpienia wywiera wpływ procedura tworzenia rządu. Jego skład nie jest bowiem konsekwencją dominacji w parlamencie jednej partii politycznej, czy nawet koalicji kilku ugrupowań. O składzie gabinetu decyduje bowiem Prezydent Federacji Rosyjskiej. Konstytucyjna procedura powoływania rady ministrów jest bowiem tak skonstruowana, iż inicjatywa dotycząca desygnowania premiera oraz powołania członków jego gabinetu należy wyłącznie do głowy państwa. Duma tylko udziela, lub nie, wotum zaufania rządowi. Jednakże po trzykrotnej odmowie poparcia dla składu rządu zaproponowanego przez prezydenta, ten ostatni podejmuje decyzję o rozwiązaniu Dumy. Na żadnym etapie przedstawionego trybu powołania rady ministrów inicjatywa nie przechodzi na rzecz parlamentu. Oznacza to, iż w praktyce wynik wyborów do Dumy nie przekłada się na możliwość sprawowania władzy wykonawczej przez zwycięskie ugrupowanie polityczne. Nie zachęca to do tworzenia jakichkolwiek trwałych sojuszy. Nie mają one praktycznie większego znaczenia z wyjątkiem prac wewnątrz parlamentu. Podział sta- 
nowisk wewnątrz niższej izby oraz działalność ustawodawcza stanowi jedyną zachętę do zawierania porozumień. Mają one jednak przede wszystkim charakter taktyczny i jak dotychczas nie zaowocowały trwalszą współpracą międzypartyjną.

\section{Od monopartyjności do silnej fragmentaryzacji}

Pluralizacja życia politycznego Rosji zaczęła się jeszcze przed formalnym rozpadem Związku Radzieckiego. Można się jej doszukać już w połowie lat osiemdziesiątych, kiedy to pod koniec 1985 r. zaczęły powstawać w poszczególnych republikach i krajach ruchy społeczne i organizacje stawiające sobie za cel odrodzenie tożsamości narodowej. Wprawdzie często miały one tylko nieformalny charakter, ale stanowiły zalążek późniejszych organizacji i partii politycznych. Krokiem milowym na drodze do pluralizmu organizacyjnego stała się decyzja III Zjazdu Deputowanych Ludowych ZSRR o usunięciu z Konstytucji ZSRR zapisu o kierowniczej roli Komunistycznej Partii Związku Radzieckiego i stworzenia konstytucyjnych warunków do pluralizmu politycznego ${ }^{3}$. Był to akt zamykający trwającą od końca lat osiemdziesiątych dyskusję o możliwości odstąpienia od dogmatu o kierowniczej roli partii komunistycznej oraz systemu monopartyjnego. Problem ten był bardzo złożony i delikatny. Nawet czołowi przywódcy i zdeklarowani zwolennicy pieriestroiki długo nie mieli odwagi podważać kierowniczej roli KPZR. Była ona traktowana jako pewnego rodzaju świętość i dogmat socjalizmu. Nawet B. Jelcyn, jeden z czołowych reformatorów tego okresu, jeszcze w swym wystapieniu z 7 marca 1989 r. na wiecu wyborczym, gdy ubiegał się o mandat deputowanego ZSRR, stwierdził że ,zanim postawi się pytanie o możliwość wprowadzenia wielopartyjności w życie, trzeba dać narodowi możliwość wykazania się w tej dziedzinie - konkretnie każdemu obywatelowi kraju. Moje stanowisko jest następujące: myślę, że dzisiaj nasze społeczeństwo nie jest gotowe do utworzenia innych partii’"4.

Badanie socjologiczne przeprowadzone na reprezentatywnej próbie ludności Związku Radzieckiego w grudniu 1989 r. wykazało duże poparcie społeczne dla natychmiastowej likwidacji konstytucyjnego zapisu

3 Trzeci Zjazd Deputowanych Ludowych ZSRR odbył się w dniach 12-15 marca 1990 r. Na tym samym zjeździe wybrano na Prezydenta ZSRR M. Gorbaczowa.

4 B. Jelcyn, Polumierami nje obojtiś, „Aprjel” 1989, nr 1, s. 204. 
o kierowniczej roli KPZR. Takiego zdania było aż 35\% badanych. Podobna liczba respondentów, bo 33\%, opowiedziała się za koniecznością szybkiego usunięcia wspomnianego zapisu z Konstytucji. Tylko 19\% respondentów optowała za zachowaniem dotychczasowych konstytucyjnych gwarancji kierowniczej roli partii komunistycznej i jednopartyjności ${ }^{5}$.

Mniej radykalni w swoich poglądach byli deputowani. Zaproponowany w porządku obrad zjazdu punkt dotyczący zmiany konstytucyjnego zapisu o kierowniczej roli KPZR nie został przyjęty. Dokonano jednak uzupełnienia art. 51 Konstytucji w ten sposób, iż zezwalał on obywatelom na zrzeszanie się $w$ partiach politycznych.

Na I Zjeździe Deputowanych Ludowych RSFRR 12 czerwca 1990 r. w uchwalonej Deklaracji suwerenności państwowej RSFRR znalazło się stwierdzenie, iż ,RSFRR gwarantuje swoim obywatelom, partiom politycznym, organizacjom społecznym, masowym ruchom i organizacjom religijnym, działającym w ramach Konstytucji RSFRR, równe możliwości prawne do udziału we władzach państwowych i społecznych"6. W ślad za tym postanowieniem Zjazd Deputowanych Ludowych RSFRR dokonał 16 czerwca zmiany Konstytucji RSFRR znosząc zapis o kierowniczej roli partii komunistycznej i wprowadzając gwarancję udziału partii politycznych i innych organizacji społecznych w wypracowywaniu polityki państwa i kierowaniu sprawami państwowymi i społecznymi ${ }^{7}$. Były to więc zmiany o charakterze rewolucyjnym. Wprowadzały one w efekcie zasadę pluralizmu politycznego i znosiły monopol jednej partii.

17 października 1990 uchwalona została przez Radę Najwyższą ZSRR ustawa $O$ organizacjach społecznych ${ }^{8}$. Na jej podstawie można było tworzyć również partie polityczne. Dała ona wyraźny impuls do procesu dynamicznego rozwoju organizacji społecznych i politycznych, w tym także partii politycznych. Wprawdzie de facto w Rosji działały już pojedyncze

${ }^{5}$ N. Piszczulin, Wtoroj Sjezd narodnych dieputatow SSSR, „Izwiestija” z 1 stycznia 1990.

${ }^{6}$ Przeobrażenia ustrojowe w republikach dawnego ZSRR, red. E. Zieliński, Warszawa 1993, s. 284.

7 Por. E. Zieliński, Wspótczesna Rosja. Studium polityczno-ustrojowe, Warszawa 1994, s. 95.

8 Wiedomosti Sjezda narodnych dieputatow SSSR i Wierchownogo Sowieta SSSR, 1990 , nr 42, poz. 839. Własny akt prawny dotyczący rejestracji i działalności organizacji społecznych na terytorium Federacji Rosyjskiej wydała Rada Najwyższa RFSRR 18 grudnia $1991 \mathrm{r}$. 
partie i ruchy polityczne, ale dopiero wzmiankowana ustawa sformalizowała tego rodzaju działania i je uprawomocniła. W marcu 1991 r. w Ministerstwie Sprawiedliwości było zarejestrowanych już 35 partii politycznych. Ocenia się, iż bez formalnej rejestracji działało ich wielokrotnie więcej ${ }^{9}$.

Wydanie wspomnianej ustawy zakończyło, w sensie formalnym, funkcjonujący przez kilkadziesiąt lat system monopartyjny. Przełamanie monopolu partii komunistycznej uzewnętrzniło różnorodność orientacji politycznej społeczeństwa. Jak grzyby po deszczu pojawiały się na rosyjskiej scenie politycznej coraz to nowe ugrupowania polityczne. Ich oblicze polityczne oraz struktury organizacyjne często były trudne do określenia. Przyczyną takiego stanu rzeczy była przede wszystkim ogromna spontaniczność w ich powstawaniu. Owocowało to dużym rozdrobnieniem sceny politycznej. Partie i organizacje polityczne o bardzo podobnych założeniach programowych często o sobie nic nie wiedziały. Nie występowała również tendencja do tworzenia porozumień i koalicji, bowiem większość ugrupowań politycznych była budowana ad personom, czyli na zapotrzebowanie lidera, który w ten sposób tworzył swoje zaplecze polityczne. Cechą charakterystyczną genezy partii politycznych w Rosji był w tym okresie znaczny udział w ich tworzeniu aparatu państwowego. To urzędnicy państwowi pierwsi dostrzegli korzyści płynące z kierowania własnym ugrupowaniem politycznym. Stwarzało to sprzyjające warunki do kontynuowania i rozwoju własnej kariery politycznej.

W celu demonopolizacji i depolityzacji zakładów pracy Prezydent Rosji wydał 20 lipca 1991 r. dekret, w którym nakazał zaprzestanie działalności zorganizowanych struktur politycznych i partyjnych we wszystkich zakładach pracy, instytucjach, organach państwowych i urzędach ${ }^{10}$. Dekret spowodował protesty o łamanie praw i swobód obywatelskich. Zgodnie z dekretem osoby znajdujące się na służbie państwowej nie mogły być w swej działalności służbowej związane decyzjami partii politycznych ${ }^{11}$.

9 D. W. Szutko, Stanowlenije mnogopartijnoj sistiemy w Rossijskoj Fiedieracyi (politiko-prawowyje woprosy), Moskwa 1993, s. 76.

10 Ukaz Priezidienta RSFSR ot 20 ijula 1991 g. O priekraszczenii dejatielnosti organizacyonnych struktur politiczeskich partii $i$ massowych obszczestwiennych dwizenij $w$ gosudarstwiennych organach, uczriezdienijach i organizacyjach RSFSR, „Wiedomosti Sjezda narodnych dieputatow RSFSR i Wierchownogo Sowieta RSFSR" 1991, nr 31, poz. 1035.

11 E. Zieliński, Wspótczesna Rosja ..., op. cit., s. 96. Zakaz posiadania przez partię jednostek organizacyjnych w zakładach pracy wprowadzała również polska ustawa o partiach politycznych uchwalona przez Sejm 28 lipca 1990 r. 
Po puczu sierpniowym 1991 r. prezydent B. Jelcyn wydał 23 sierpnia 1991 r. dekret ${ }^{12}$, w którym zawiesił działalność partii komunistycznej na terytorium Federacji Rosyjskiej, motywując to udzieleniem przez KPZR poparcia dla puczystów i stworzenia własnych nadzwyczajnych komitetów, co pozostało w sprzeczności z Konstytucją. Na mocy tego dekretu organy spraw wewnętrznych przejęły majątek partii komunistycznej. W kolejnym dekrecie z 6 września 1991 r. Prezydent Rosji zakazał działalności KPZR i Komunistycznej Partii RSFRR, a także nakazał przejęcie majątku partii na własność państwa ${ }^{13}$. W ten sposób ostatecznie nastąpiło rozwiązanie partii komunistycznej. Przez cały ten czas pozostawała ona mocno zrośnięta $\mathrm{z}$ aparatem państwowym, stanowiąc podstawę biurokracji socjalistycznej. Zakończył się tym samym trwający ponad 70 lat okres monopolistycznych rządów tej partii w Rosji i Związku Radzieckim. Przedsięwzięcia te nie spotkały się z reakcją społeczną. Ludzie mieli dość rządów wszechwładnej i wyobcowanej od społeczeństwa siły, której aparat nie był w stanie nawet zorganizować samoobrony i zdał się na zejście ze sceny politycznej ${ }^{14}$.

\section{Partie w okresie raczkującej demokracji}

W drugiej połowie lat osiemdziesiątych można było dostrzec dwie tendencje dotyczące przeobrażeń ustrojowych związanych z systemem partyjnym. Zwolennicy jednej stawiali na powolne budowanie systemu wielopartyjnego i przygotowywali się do utworzenia niezależnych od KPZR partii politycznych poprzez powoływanie organizacji i porozumień o bardzo różnym, nie zawsze politycznym charakterze. Grupy te często miały nieformalny charakter. W sprzyjających okolicznościach miałyby one stanowić zalążek nowego, pluralistycznego systemu partyjnego. Zwolennicy drugiej drogi dążyli do tego samego poprzez tworzenie w łonie partii komunistycznej frakcji i grup nieformalnych, które w przy-

12 Ukaz Priezidienta RSFSR ot 23 awgusta 1991 g. O priostanowlenii diejatielnosti Kommunisticzeskoj partii RSFSR, „Wiedomosti Sjezda narodnych dieputatow RSFSR i Wierchownogo Sowieta RSFSR" 1991, nr 35, art. 1149.

13 Ukaz Priezidienta RSFSP ot 6 nojabria $1991 \mathrm{~g}$. O diejatielnosti KPSS i KP RSFSR, „Wiedomosti Sjezda narodnych dieputatow RSFSR i Wierchownogo Sowieta RSFSR" 1991, nr 45, art. 1537.

14 E. Zieliński, Wspótczesna Rosja..., op. cit., s. 96-97. 
szłości mogłyby stanowić samodzielne podmioty na scenie politycznej. Na razie jednak występowali z pozycji reformatorów, chcących udoskonalać jakościowo istniejący system z kierowniczą rolą partii komunistycznej. Podobnie jak w innych krajach Europy Wschodniej, również w Rosji dużą popularnością zaczęła się cieszyć doktryna socjaldemokratyczna. Stąd powstanie takich ugrupowań, jak np. Socjalistyczna Inicjatywa (Socyalisticzeskaja iniciatiwa) czy Akcja Narodowa (Narodnoje diejstwije). Jednakże pod koniec 1988 r. socjalizm został wyparty przez koncepcje określane jako budowa podstaw demokracji. W istocie koncepcja ta polegała na stworzeniu systemu politycznego opartego na podstawowych mechanizmach charakterystycznych dla demokracji i społeczeństwa obywatelskiego.

Trzeba pamiętać, iż inicjatorami pieriestroiki byli działacze partii komunistycznej. Wprawdzie byli oni zdeterminowani przeprowadzić poważne reformy w systemie politycznym, ale nie zakładali jego radykalnej zmiany, a jedynie modyfikację. Nie zamierzali więc doprowadzić do zmiany ustrojowej. Zmiany organizacyjne, jakie pojawiły się na radzieckiej scenie politycznej były raczej efektem utracenia kontroli kierownictwa KPZR nad wydarzeniami w państwie i samej partii.

Wprawdzie, jak wspomniano wyżej, pierwsze partie polityczne pojawiły się już pod koniec lat osiemdziesiątych, to ich prawdziwy rozkwit zaczął się dopiero po usunięciu z Konstytucji ZSRR w marcu 1990 r. zapisu o kierowniczej roli partii komunistycznej. Wielu obserwatorów rosyjskiej sceny politycznej w tym okresie uważało, że powstające jak grzyby po deszczu partie i ugrupowania polityczne nie różniły się w istotny sposób od siebie pod względem programowym. Nie jest to niczym dziwnym, zważywszy iż znakomita większość ówczesnych partii politycznych opierała się, w sensie ideologicznym, na wspólnej, uniwersalnej koncepcji budowy podstaw demokracji, co w konsekwencji musiało prowadzić do powstawania zbliżonych programów politycznych. Rodzi się więc pytanie, dlaczego, wobec bliskości podstaw ideowo-programowych wszystkich ugrupowań demokratycznych, nie powstała jedna partia polityczna? Odpowiedzi można poszukiwać w genezie organizacyjnej tych partii. Część z nich, tak jak np. Socjaldemokratyczna Partia Rosji (Socyał-diemokraticzeskaja partija Rossii - SDPR ${ }^{15}$ powstały jako alternatywa dla

15 SDPR została utworzona w styczniu 1990 r. z inicjatywy uczestników zjazdu założycielskiego Asocjacji Socjaldemikratycznej (Socyał-diemokraticzeskaja assocyacyja - SDA). Zjazd założycielski SDPR odbył się w maju tego samego roku. W skład 
partii komunistycznej. Jej członkowie nigdy nie należeli do KPZR lub wystapili z tej partii zaraz na początku pieriestroiki. Stanowili ten nurt tworzącego się systemu partyjnego, który w swej genezie był oddzielony od partii komunistycznej. Druga grupe partii politycznych stanowiły te, które swe korzenie miały w strukturach KPZR. Powstawały one w wyniku organizacyjnego usamodzielnienia się wewnętrznych frakcji i grup powstałych w łonie partii komunistycznej. Początkowo działały one jako tzw. kluby dyskusyjne, a później stworzyły wspólną płaszczyznę w postaci Platformy Demokratycznej w KPZR. Największą z partii politycznych mających swój rodowód w tych właśnie strukturach była Republikańska Partia Federacji Rosyjskiej (Riespublikanskaja partija Rossijskoj Fiedjeracyi - RPRF) ${ }^{16}$.

Wzajemne stosunki między partią socjaldemokratyczną a republikańską oscylowały od prób zjednoczenia do wyraźnej wrogości. Obydwie miały bardzo podobne struktury organizacyjne i liczyły w tym okresie po około 5 tys. członków. Na czele każdej z nich stał rodzaj trumwiratu, czyli trzyosobowe kierownictwo. Miało to być gwarancją kolektywnego zarządzania partią i przeciwdziałać dominacji jednostki w strukturze partii. Było to wyraźne odreagowanie występującego w partii komunistycznej silnego jednoosobowego kierownictwa traktowanego jako symbol totalitaryzmu.

Chociaż obydwie partie posiadały również zbliżone programy polityczne, to do ich ściślejszej współpracy nigdy nie doszło, nie mówiąc już o zjednoczeniu. Przyczyny były różne, ale zasadnicza wydaje się niechęć socjaldemokratów do działaczy partii republikańskiej, którzy byli silnie związani z partią komunistyczną i nie mieli wcześniej odwagi wystąpić z niej, ani przeciwstawić się dominacji komunistów w systemie politycznym.

Wprawdzie w okresie, o którym mówimy, w Rosji dominowała już koncepcja budowy podstaw demokracji, ale występowały także inne nurty

partii weszło wiele nieformalnych grup o charakterze socjaldemokratycznym m.in. Demokratyczna Pieriestrojka, Pieriestrojka, Konfederacja Socjaldemokratyczna. Została oficjalnie zarejestrowana w marcu 1991 r. Obecnie nosi nazwę Socjaldemokratyczna Partia Federacji Rosyjskiej, ale skrótowa forma nazwy pozostała taka jak wcześniej.

${ }_{16}$ RPRF została utworzona w listopadzie 1990 r. na bazie ruchu Platforma Demokratyczna w KPZR po jej wystapieniu z KPZR na XXVIII zjeździe partii komunistycznej w czerwcu $1990 \mathrm{r}$. Została zarejestrowana jako partia polityczna 14 marca 1991 r. i działa do chwili obecnej. 
ideowe. Do najważniejszych zaliczyć można ideologie nacjonalistyczne. Ich zwolennicy chętniej nazywali się patriotami niż nacjonalistami. Wprawdzie u zarania demokratyzacji systemu partyjnego w Rosji nie odegrały one znaczniejszej roli, to jednak w latach następnych wpisały się wyraźnie w rosyjski krajobraz polityczny. Ugrupowania te chętnie odwoływały się do tradycji i historii Rosji, również tej najdawniejszej. Lansowały one specyficzna, narodowo-historyczną drogę budowania nowego społeczeństwa postradzieckiego. Jednym z prekursorów tego ruchu było zalegalizowane już w 1983 r. stowarzyszenie „Pamięć” („Pamiat”). Odegrało ono bardzo ważną rolę w formowaniu się nowych podziałów na radzieckiej scenie politycznej. Do dzisiaj pozostaje nie wyjaśniony stosunek kierownictwa KPZR do tego stowarzyszenia. Niektórzy badacze uważają, iż bez poparcia przynajmniej części ówczesnego kierownictwa partyjnego działalność „Pamięci” nie byłaby możliwa ${ }^{17}$. Wprawdzie stowarzyszenie pozwalało sobie na wyraźną krytykę ówczesnych władz partyjnych i państwowych, jednakże pozostawało w niektórych kwestiach bardzo zbliżone do najbardziej zachowawczej części kierownictwa KPZR. Ta zgodność dotyczyła między innymi niechęci do demokracji zachodniej, gospodarki rynkowej czy zachodnich wzorców kultury masowej.

W okresie poprzedzającym odbywające się w 1990 r. wybory do organów władzy ustawodawczej republik, zaczęto tworzyć bloki wyborcze, które spełniały w systemie politycznym te same funkcje, co partie polityczne. Warto zwrócić uwagę, iż formalnie powoływanie tych bloków było $\mathrm{w}$ wielu republikach niezgodne z prawem, ponieważ żadne przepisy nie przewidywały ich tworzenia. Nikt jednak nie zwracał na to uwagi i metodą faktów dokonanych ten rodzaj organizacji politycznych zakorzenił się na stałe w systemie politycznym współczesnej Rosji i w nieco zmienionej formie funkcjonuje do dziś. Z tym, iż współcześnie ich tworzenie i działalność jest uregulowana prawnie. Nie powoduje to jednak ograniczenia ich samodzielności i swobody działania.

Wybory deputowanych ludowych przeprowadzone w marcu $1990 \mathrm{r}$. dały nowy asumpt do przyspieszenia strukturyzacji rosyjskiego systemu partyjnego. Duży wpływ na przyszłe podziały rosyjskiej sceny politycznej wywarła koalicja wyborcza „Demokratyczna Rosja” („Diemokraticzeskaja Rossija" - DR). Powstała ona w październiku 1990 r. w wyniku po-

17 Por. G. W. Gołosow, Proischożdienije sowriemiennych rossijskich politiczeskich partij, 1987-1993, w: Pierwyj elektoralnyj cykt w Rossii 1993-1996 gg., red. W. Gielman, G. Gołosow, J. Mieleszkina, Moskwa 2000, s. 83. 
rozumienia wielu nieformalnych wtedy grup i organizacji politycznych oraz komitetów wyborców utworzonych w celu poparcia zgłaszanego przez nie kandydata na deputowanego. W jej skład weszło 9 partii politycznych $^{18}, 19$ organizacji społecznych i kilka frakcji deputowanych do parlamentu ZSRR. „Demokratyczna Rosja” miała zasięg ogólnorosyjski, co w tym czasie było zjawiskiem wyjątkowym, ponieważ nowe ugrupowania polityczne raczej koncentrowały swą działalność na terenie największych miast i nie były w stanie stworzyć swych struktur w terenie. Podstawowe założenia programowe były oparte na koncepcjach budowy społeczeństwa obywatelskiego i demokratycznego systemu politycznego. Pojawiły się więc w programie hasła wolności, demokracji, praw człowieka, pluralizmu politycznego, wolnych wyborów oraz gospodarki rynkowej. „Demokratyczna Rosja” uzyskała dobre wyniki już podczas wyborów deputowanych do parlamentu RFSRR w 1990 r., szczególnie w dużych aglomeracjach miejskich. Zwieńczeniem jej sukcesów politycznych był wybór B. Jelcyna na Przewodniczącego Rady Najwyższej RFSRR.

Wbrew oczekiwaniom spektakularny sukces „Demokratycznej Rosji” nie spowodował konsolidacji tego ugrupowania. Wręcz przeciwnie. Po wyborach nastapił jego faktyczny rozpad. Było to spowodowane przede wszystkim instrumentalnym potraktowaniem organizacji przez kandydatów do parlamentu. Nie czuli się oni związani w żaden sposób z organizacją, która pomogła im zdobyć mandat. Zaraz po wyborach wycofali się z udziału w „Demokratycznej Rosji”, realizując swoje własne cele ${ }^{19}$.

W latach 1990-1993 „Demokratyczna Rosja” przeszła swoistą ewolucję. Z porozumienia wyborczego przekształciła się we frakcję parlamentarną, która miała charakter porozumienia wielu różnych ugrupowań politycznych i pozostała wewnętrznie skłócona. W efekcie, na skutek licznych rozłamów i secesji, ugrupowanie to rozpadło się całkowicie w połowie $1993 \mathrm{r}$.

Dążenie do konsolidacji nie ominęło także ugrupowań nacjonalistycznych. W grudniu 1989 r. utworzyły one wspólny Blok Sił Narodowo-Pa-

18 Były to min: Chłopska Partia Rosji (Kriestjanskaja partija Rossii), Narodowa Partia Rosji (Nacionalnaja partija Rossii), Republikańska Partia Federacji Rosyjskiej (Riespublikanskaja partija Rossijskoj Fiedieracyi), Socjaldemokratyczna Partia Rosji (Socyał-diemokraticzeskaja partija Rossii), Rosyjska Partia Socjalno-Liberalna (Rossijskaja socyalno-libieralnaja partija).

19 M. S. Fish, Democracy from Scratch: Opposition and Regime in the New Russian Revolution, Princeton 1995, s. 134. 
triotycznych (Błok narodno-patrioticzeskich sił). Nie odegrał on jednak znaczącej roli w wyborach parlamentarnych. Jego porażka spowodowana była zapewne brakiem wyrazistości politycznej. Przywódcy ugrupowań nacjonalistycznych lawirowali pomiędzy dwoma głównymi blokami politycznymi, a mianowicie „demokratami” z jednej strony, a różnymi formacjami obstającymi za dotychczasowym porządkiem. Dodatkowo ich niejasne stanowisko w kwestii demokracji oraz wręcz niechęć do wprowadzenia zasad gospodarki rynkowej doprowadziło do porażki wyborczej.

\section{Pierwsze rywalizacyjne wybory}

Kampania wyborcza w roku 1990 przyczyniła się wyraźnie do rozwoju systemu partyjnego Rosji. Chodziło nie tylko o zwiększenie liczby uczestników gry politycznej. Nowo powstające ugrupowania, w tym również partie polityczne, tworzyły sprzyjające warunki do wzrostu politycznej aktywności obywateli. Wzmagało się zainteresowanie partycypacją polityczną. Pobudzone indywidualne ambicje do robienia kariery politycznej sprzyjały tworzeniu nowych organizacji lub szukania wsparcia w już istniejących. Nadal trwał dualizm związany z podziałem sceny politycznej. Z jednej strony na arenę rywalizacji politycznej wkraczały nowe ugrupowania demokratyczne, a z drugiej trwały na niej zakorzenione silnie i wciąż jeszcze sprawne struktury partii komunistycznej. Były one nadal atrakcyjnym zapleczem pozwalającym na odniesienie sukcesu wyborczego.

Pod koniec maja 1990 r. powstała Demokratyczna Partia Rosji (Diemokraticzeskaja partija Rossii - DPR). Utworzono ją na bazie Leningradzkiego Frontu Narodowego (Leningradskij narodnyj front), Moskiewskiego Zjednoczenia Wyborców (Moskowskoje objedinienije izbiratielej) oraz struktur ruchu „Demokratyczna Rosja”. Ten ostatni pozostawał w DPR do jesieni $1991 \mathrm{r}$.

Warto w tym miejscu zwrócić uwagę na szczególną cechę niektórych rosyjskich partii politycznych. Nierzadko są one tworzone w wyniku połączenia samodzielnych ugrupowań politycznych. W tym również partii politycznych. Co jest jednak pewnym ewenementem, często łączące się partie pozostają autonomiczną strukturą organizacyjną w ramach nowego podmiotu politycznego. Nie dochodzi więc do pełnej integracji. W konsekwencji znacznie utrudnia to zbudowanie spójnej wewnętrznie struktury 
organizacyjnej i programowej. W efekcie mamy do czynienia z czymś w rodzaju frakcji działającej wewnątrz partii politycznej. Spójność takiej organizacji jest wątpliwa. Często prowadzi to, szczególnie wobec rozbieżności interesów przywódców, do oderwania się poszczególnych ugrupowań wewnętrznych (frakcji) od partii. Skutkuje to ciągłą destabilizacją sceny politycznej.

Na czele DPR stanął jeden z jej twórców Nikołaj Trawkin ${ }^{20}$. Podjął on działania zmierzające do stworzenia sieci ogólnokrajowej struktury partii. Udało mu się przekonać do tej idei wielu liderów regionalnych ugrupowań demokratycznych, chociaż nie było to zadanie łatwe. Lokalni przywódcy niechętnie pozbywali się własnych wpływów na rzecz odległego moskiewskiego centrum. Nie mniej jednak N. Trawkinowi udało się stworzyć ogólnorosyjską partię polityczną, która niedostatki i niejasności programowe rekompensowała silną strukturą wewnętrzną. Była ona budowana na wzór partii komunistycznej. Ten schemat organizacyjny miał zapewnić jej sukces w konfrontacji z KPZR ${ }^{21}$.

Obok partii demokratycznych kolejną dużą grupę stanowiły partie chrześcijańsko-demokratyczne. Pod względem programów politycznych nie różniły się one w istotny sposób od ugrupowań nazywanych demokratycznymi. W sierpniu 1989 r. powstał Związek Chrześcijańsko-Demokratyczny (Christiansko-diemokraticzeskij sojuz - ChDS). Już w kwietniu roku następnego wystąpiła z partii grupa działaczy, tworząc własną partię Rosyjski Ruch Chrześcijańsko-Demokratyczny (Rossijskoje christiansko-diemokraticzeskoje dwiżenije - RChDD). Ugrupowanie to utożsamiało demokrację i tradycję narodową wyłącznie z prawosławiem.

Do organizacji o demokratycznej proweniencji należą także ugrupowania tzw. konstytucyjnych demokratów. Większość z nich nawiązywała do przedrewolucyjnej tradycji politycznej Rosji. Najchętniej do koncepcji tzw. „kadetów”. Już we wrześniu 1989 r. utworzono Związek Konstytucyjnych Demokratów (Sojuz konstitucyonnych diemokratow) przekształcony następnie w Partię Konstytucyjnych Demokratów (Partija konstitucyonnych diemokratow - PKD). Na skutek rozpadu tego ugrupowania powstała Konstytucyjno-Demokratyczna Partia - Partia Ludowej

20 N. Trawkin był wcześniej jednym z bardziej znanych działaczy Platformy Demokratycznej w KPZR.

21 Por. G. W. Gołosow, Proischożdienije sowriemiennych rossijskich politiczeskich..., op. cit., s. 87. 
Wolności (Konstitucyonno-diemokraticzeskaja partija - Partija narodnoj swobody - KDP-PNS).

W niektórych kwestiach RChDD i KDP-PNS niewiele różniły się od SDPR i RPFR. Wszystkie one wyrastały z jednego pnia - organizacji demokratycznych. Następnie weszły w skład „Demokratycznej Rosji”. Dopiero później ich drogi się rozeszły. SDPR i RPFR łączyły nie tylko podobne koncepcje programowe, ale również zbliżone założenia organizacyjne. Ich cechą charakterystyczną było stosowanie zasady kolegialnego kierownictwa. Od obydwu partii odrywały się pojedyncze grupy działaczy i tworzyły własne partie polityczne. Nowo powstałe organizacje opierały się jednak na silnym jednoosobowym kierownictwie. Nowi przywódcy nie wierzyli bowiem w możliwość skutecznego funkcjonowania partii kierowanej przez kilku liderów jednocześnie. Zjawisko powyższe nasiliło się szczególnie po zmianie charakteru reżimu politycznego w Rosji. Niektórzy działacze, uznając iż ich partia lub oni osobiście, nie mają szans na odniesienie sukcesu w ramach dotychczasowych struktur, postanawiali wraz z grupą zdominowanych przez siebie współtowarzyszy założyć odrębne ugrupowanie polityczne. Uważali, iż tym samym zwiększą własne szanse na zwycięstwo wyborcze ${ }^{22}$.

Ważne znaczenie dla ukształtowania się rosyjskiej sceny politycznej miało utworzenie w marcu 1990 r. Liberalno-Demokratycznej Partii Rosji (Libieralno-diemokraticzeskaja partija Rossii - LDPR). Powstała ona na bazie frakcji partii „Związek Demokratyczny” („Diemokraticzeskij sojuz"). Początkowo nosiła nazwę Liberalno-Demokratyczna Partia Związku Radzieckiego. Pod obecną nazwą występuje od roku 1992. Na jej czele stoi W. Żyrinowski. Jest to partia, która od początku swego istnienia była silnie zcentralizowana. Faktycznie cała władza jest skupiona w ręku przywódcy. Utworzyła swoje struktury w większości podmiotów Federacji Rosyjskiej. Jej program polityczny został oparty o założenia demokratycznego liberalizmu, ale jest bardzo niekonsekwentny. Partia W. Żyrinowskiego wypełniła lukę, jaka powstała na rosyjskiej scenie politycznej na skutek wykruszenia się partii o charakterze liberalno-narodowym. Praktycznie skupiła ona wszystkie znaczące siły o programach prawicowo-liberalnych. Jej program, chociaż pełen sprzeczności i niejasny, oparty był na silnych wątkach nacjonalistycznych. Tak naprawdę to właśnie elementy nacjonalistyczne biorą w nim górę nad liberalnymi. Te ostatnie sta-

22 Ibidem, s. 88. 
nowią jedynie otoczkę dla prawdziwego oblicza programowego partii W. Żyrinowskiego. W pierwszym okresie budowy społeczeństwa demokratycznego w Rosji program LDPR przyciagał swym populizmem szerokie rzesze wyborców. Stąd duży sukces partii w wyborach parlamentarnych w roku 1993 i trzecie miejsce W. Żyrinowskiego w wyborach prezydenckich w 1991 r. W następnych latach partia i jej lider uzyskiwali już coraz gorsze wyniki.

\section{Walka o schedę po KPZR}

Na przełomie lat osiemdziesiątych i dziewięćdziesiątych podział sceny politycznej w Rosji jeszcze się nie ukształtował, ale zaznaczyły się już wyraźnie podstawowe nurty programowe. Pierwszą okazją do konfrontacji stały się wybory parlamentarne w roku 1990. Ale prawdziwa próba sił nastąpiła dopiero rok później, podczas wyborów Prezydenta Rosji. Stały się one konfrontacją pomiędzy starym układem politycznym reprezentowanym przez KPZR i nowymi siłami politycznymi. Największym ugrupowaniem niekomunistycznym był ruch „Demokratyczna Rosja”. Poparł on jednego kandydata na prezydenta - B. Jelcyna. Podobnie uczyniły DPR, SDPR, RPRF, RChDD, KDP-PNS oraz kilka innych ugrupowań politycznych. Kontrkandydatami B. Jelcyna był W. Żyrinowski zgłoszony przez swoją partię LDPR oraz czterech kandydatów popieranych przez KPZR. Trudno wytłumaczyć dlaczego komuniści zgłosili aż czterech kandydatów. Było przecież oczywistym, iż głosy zwolenników KPZR rozproszą się na poszczególnych kandydatów i tym samym obniżą szansę każdego z nich na zwycięstwo.

Wybór B. Jelcyna w pierwszej turze głosowania oznaczał bezapelacyjne zwycięstwo „demokratów”. Tym samym udowodniono, iż nowe siły polityczne potrafiły już skutecznie konkurować z dotychczasową siłą przewodnią, czyli KPZR. Ale dobry wynik W. Żyrinowskiego (7,8\% głosów) oznaczał, iż rysujący się wcześniej dychotomiczny podział sceny politycznej w Rosji na „demokratów” i komunistów przestał być aktualny. Umocniła się nowa siła polityczna, czyli „nacjonaliści”. W przyszłości mieli stanowić oni poważną alternatywę dla dwóch wcześniej wzmiankowanych opcji ideowych.

Po wyborach prezydenckich Rosja weszła w nową fazę rozwoju systemu partyjnego. Porażka wyborcza kandydatów KPZR unaoczniła słabnąca siłę partii komunistycznej. Ośmieliła liderów ugrupowań demokratycz- 
nych do podjęcia działań zmierzających do wyparcia komunistów z dominującej pozycji w systemie politycznym. Lider DPR N. Trawkin podją wysiłki na rzecz stworzenia pod sztandarami swojej partii jednolitego, silnego ugrupowania zdolnego wypełnić na nowej scenie politycznej miejsce zajmowane dotychczas przez KPZR. Jego działania zmierzały do przyłączenia do DPR innych partii, a w szczególności SDPR i RPRF, które były najbliższe ideowo. Wysiłki te nie zakończyły się jednak sukcesem i do połączenia partii nie doszło.

Sukces B. Jelcyna spowodował pewne działania również po przeciwnej stronie sceny politycznej. Słabnące wpływy KPZR spowodowały konieczność poszukiwania sposobów na odnowę partii komunistycznej. Antygorbaczowska opozycja wewnątrzpartyjna doprowadziła do utworzenia w 1991 r. Demokratycznej Partii Komunistów Rosji (Diemokraticzeskaja partija kommunistow Rossii), na czele której stanął wiceprezydent Rosji A. Ruckoj oraz Ruchu Demokratycznych Reform (Dwiżenije diemokraticzeskich rieform - DDR). Na czele tego ostatniego ugrupowania stali m.in. G. Popow, A. Sobczak, E. Szewardnadze, I. Silaiew. W jego skład weszła również, na zasadach członkostwa zbiorowego, Republikańska Partia Federacji Rosyjskiej.

Jesienią 1991 r. sytuacja na rosyjskiej scenie politycznej znacznie się skomplikowała. Podział ugrupowań politycznych nie był już tak jednoznaczny jak wcześniej. Zarówno część ugrupowań określanych jako demokratyczne, jak i komunistyczne pozostała poza sferą realnych wpływów politycznych. Powodowało to gorycz i rozczarowanie wśród członków partii, jak i zaniepokojenie liderów. Pozostawało albo czekać na następne wybory, licząc na sukces pozwalający na uczestniczenie w sprawowaniu władzy, lub zdecydować się na zmianę koncepcji programowych i przejść do opozycji wobec ,obozu reform”.

Narastający konflikt między B. Jelcynem a A. Ruckojem spotęgował tylko proces obumierania kierowanego przez wiceprezydenta ugrupowania $^{23}$. Odsunięty przez prezydenta od podejmowania jakichkolwiek decyzji krytykował wszelkie działania podejmowane przez władzę wykonawczą w Rosji. W efekcie partia kierowana przez A. Ruckoja stała się partią opozycyjną ${ }^{24}$.

23 Jesienią 1991 r. partia A. Ruckoja zmieniła nazwę z Demokratycznej Partii Komunistów Rosji na Ludową Partię „Wolna Rosja” (Narodnaja partija „Swobodnaja Rossija”).

24 G. W. Gołosow, Proischożdjenije sowrjemjennych rossijskich politiczjeskich..., op. cit., s. 92 . 
W tym czasie zarysował się wyraźny podział sceny politycznej na dwa główne nurty: komunistyczny i nacjonalistyczny. Z tym, iż wzmiankowany dychotomiczny układ wcale nie był jednoznacznie oparty na przesłankach ideowych czy programowych. Rozróżnienie między ugrupowaniami komunistycznymi i nacjonalistycznymi dotyczyło sfery raczej deklaracji niż założeń programowych. W obydwu nurtach główną rolę odgrywali byli działacze KPZR.

Do bardziej znanych ugrupowań nacjonalistycznych należał Rosyjski Związek Ogólnonarodowy (Rossijskij obszczenarodnyj sojuz - ROS), na którego czele stał S. Baburin. Lider tej organizacji przeszedł jednak do zdecydowanie antyjelcynowskiej frakcji „Rosja” (,Rossija”). Warto przypomnieć, iż w ROS aktywnie działał późniejszy lider komunistów rosyjskich G. Ziuganow.

W 1992 r. ugrupowania określane w Rosji jako nacjonalistyczne przeszły do opozycji wobec B. Jelcyna. Najznaczniejszą rolę w tym nurcie ideowym zaczął odgrywać utworzony w październiku 1992 r. Front Ocalenia Narodowego (Front nacyonalnogo spasienija - FNS). Jego kierownictwo poddawało ostrej krytyce działalność prezydenta z pozycji zdeklarowanych przeciwników nowego porządku. W kierownictwie FNS znaleźli się liderzy opozycyjnych frakcji parlamentarnych oraz przywódcy niektórych partii politycznych, np. ROS i RNRP. Do Frontu Ocalenia Narodowego przystapiły także partie polityczne, które wcześniej wchodziły w skład „Demokratycznej Rosji” - RChDD i KDP-PNS.

Zarówno FNS, jak i Sojusz Obywatelski nie były organizacjami o charakterze partii politycznych. Stanowiły one raczej rodzaj ruchu społecznego o dosyć luźnej strukturze. Obydwie organizacje różniły się taktyką działania. Sojusz Obywatelski pretendował do roli umiarkowanej opozycji w stosunku do B. Jelcyna. Podstawową formą jego aktywności stało się wywieranie nacisku na ośrodki władzy wykonawczej. Stosowano więc taktykę, którą śmiało można określić mianem lobbingu. FNS natomiast chętniej sięgał do bardziej radykalnych metod oddziaływania. Jako orientacja polityczna, zdeklarowanie antyjelcynowska, organizował akcje protestacyjne, wiece, demonstracje oraz inne formy aktywnego wyrażania sprzeciwu wobec polityki władz ${ }^{25}$.

25 Ibidem, s. 93-94. 


\section{Powrót komunistów czy tylko nostalgia?}

Osobnym nurtem na rosyjskiej scenie politycznej były ugrupowania komunistyczne. Ich dynamiczny rozwój ilościowy nastąpił dopiero po zakazie działania, a następnie zdelegalizowaniu KPZR. Do miana spadkobiercy partii komunistycznej pretendowała utworzona w październiku 1991 r. Socjalistyczna Partia Pracujących (Socyalisticzeskaja partija trudiaszczichsia - SPT). Miała ona wyraźny socjaldemokratyczny charakter. Partia szybko stała się jednym z bardziej znanych ugrupowań w Rosji. Nie spełniły się jednak oczekiwania jej przywódców związane z pozyskaniem do swoich szeregów większości byłych członków KPZR. W efekcie partia bardzo szybko zaczęła tracić wpływy i przed wyborami do parlamentu w roku 1993 nie była już w stanie spełnić nawet wymogów dla zarejestrowania swoich list kandydatów. Z chwilą powstania KPRF znakomita większość jej członków przeszła do nowej partii komunistycznej ${ }^{26}$.

W listopadzie 1991 r. powstała jeszcze jedna partia przeciwników polityki Gorbaczowa. Rosyjska Komunistyczna Partia Robotnicza (Rossijskaja kommunisticzeskaja raboczaja partija - RKRP) utworzona została na kanwie „Komunistycznej Inicjatywy” - jednej z najbardziej pryncypialnych radykalno-komunistycznych frakcji działających w ramach $\mathrm{KPZR}^{27}$.

Po orzeczeniu wydanym przez Sąd Konstytucyjny Rosji w sprawie legalności tworzenia i działalności partii i ugrupowań komunistycznych, jak grzyby po deszczu zaczęły powstawać coraz to nowe partie o proweniencji komunistycznej. $Z$ reguły ich przywódcy mieli ambicje do stworzenia w pełni suwerennego ugrupowania. Stąd ogromne rozdrobnienie organizacyjne ruch komunistycznego. Istniejące wcześniej duże, jak na ówczesne warunki, partie komunistyczne podejmowały wysiłki w celu zjednoczenia rozproszonych, drobnych partii o tej samej proweniencji. Szczególną aktywność w tym zakresie wykazywała RKRP. Jej wysiłki nie zostały jednak uwieńczone sukcesem.

W kwietniu 1993 r. odbył się zjazd komunistów rosyjskich. Powołał on do życia nową partię pod nazwą Komunistyczna Partia Federacji Rosyj-

26 W. A. Oleszczuk, W. B. Pawlenko, Politiczeskaja Rossija: partii, błoki, lidiery. God 1997. Sprawocznik, Moskwa 1997, s. 99-101.

27 Ibidem, s. 112. Obecnie liczy ok. 20 tys. członków i nie odgrywa istotnej roli $\mathrm{w}$ rosyjskim systemie partyjnym. 
skiej. Jej liderem został G. Ziuganow ${ }^{28}$. RKRP odcięła się od nowej partii i nie tylko odmówiła wejścia w jej skład, ale obwiniła ją o współpracę z antykomunistami, odejście od zasad walki klas i w efekcie likwidatorskie tendencje wobec ruchu komunistycznego w Rosji.

W kwietniu 1993 r., po trwających rok przygotowaniach, utworzono Agrarną Partię Rosji (Agrarnaja partija Rossii - APR). Była to jeszcze jedna organizacja polityczna ściśle związana z partiami o orientacji komunistycznej. Jej program i proweniencja polityczna była na tyle jednoznaczna, iż często nazywano ją chłopskim odłamem KPRF. Została ona utworzona głównie prze działaczy politycznych i gospodarczych funkcjonujących w kompleksie agrarnym. Chcieli oni zachować swe wpływy i głównie z tego powodu utworzyli własną partię polityczną. Współpracowała ona zarówno z SPT, jak i KPRF. Wraz z upływem czasu partia ta traciła jednak wpływy polityczne. Zacieśniały się wtedy coraz bardziej jej więzi z KPRF. Chcąc zachować swój byt polityczny, zawierała jawne lub niejawne porozumienia z partią G. Ziuganowa. Obydwie partie ściśle współpracowały np. na forum parlamentu. Aby utworzyć lub wzmocnić frakcję parlamentarną APR w Dumie wstępowali do niej, na zasadzie oddelegowania z macierzystej partii, deputowani z KPRF.

Powstanie dużych partii komunistycznych doprowadziło do zmiany układu sił wewnątrz FNS. Na drugim jego zjeździe w lipcu 1993 r. faktycznie doszło do rozpadu koalicji. W terenie został on praktycznie zdominowany przez działaczy komunistycznych. Wprawdzie władze centralne nadal reprezentowały dotychczasową opcję polityczną, ale nie miały one już realnego wpływu na funkcjonowanie struktur terenowych. Z FNS wystąpił ROS oraz NRPR.

Kształtowanie się rosyjskiego systemu partyjnego w tym okresie znacznie się skomplikowało. Okazało się bowiem, iż na scenie politycznej na razie nie ma miejsca dla ugrupowań, które nie miały jasno określonych założeń programowych i jednolitych struktur organizacyjnych. Po kolei rozpadały się wszelkiego rodzaju porozumienia i sojusze. Taktyka liderów tych ugrupowań, nastawiona na realizację doraźnych celów politycznych, okazała się błędna. Po chwilowych sukcesach, w miarę krystalizowania się sceny politycznej w Rosji, mało spójne programowo

28 G. Ziuganow pod koniec 1991 r. stanął na czele Rady Narodowo-Patriotycznych Sił Rosji (Sowiet nacyonalno-patrioticzeskich sił Rossii). Było to ugrupowanie o charakterze bardziej nacjonalistycznym niż lewicowym. Wchodziło ono w skład Rosyjskiego Soboru Narodowego (RNS). 
i organizacyjnie koalicje nie wytrzymywały konkurencji z tradycyjnie zorganizowanymi partiami politycznymi. Młodej demokracji przyszło zapłacić wysoką cenę za brak przezorności, prowadzący do silnego rozdrobnienia organizacyjnego.

\section{Kryzys, czyli wzmocnienie demokracji}

Sytuacja taka sprzyjała natomiast umacnianiu się władzy wykonawczej w państwie i wzrostu politycznego znaczenia B. Jelcyna. Kryzys wrześniowy w 1993 r. był nie tylko kryzysem partii politycznych, ale przede wszystkim kryzysem demokracji w Rosji. Brak wykrystalizowanego systemu partyjnego doprowadził do próby restytucji poprzedniego systemu politycznego. Obrońcy demokracji, a za takich uważani byli zwolennicy B. Jelcyna i oczywiście sam prezydent, brutalnie tłumiąc próbę przeprowadzenia puczu, uzyskali społeczne przyzwolenie do zastosowania siły i ograniczenia mechanizmów demokracji. W efekcie jeszcze bardziej umocnili swoją pozycję polityczną. Ugrupowania tzw. reformatorów na długi okres uzyskały dominację nie tylko w sprawowaniu władzy, ale również w kreowaniu układu sił politycznych. Wywarło to niewattpliwie bardzo duży wpływ na kształt rosyjskiego systemu partyjnego.

Najbardziej stabilnymi partiami politycznymi okazały się KPRF i LDPR. One dysponowały największym zapleczem społecznym i rozbudowanymi oraz $\mathrm{w}$ miare stabilnymi strukturami organizacyjnymi.

W okresie lat 1992-1993 podejmowano szereg działań zmierzających do stworzenia politycznego zaplecza organizacyjnego dla tzw. ,rządu reform”. Działania te były w pełni zrozumiałe. B. Jelcyn musiał stworzyć własne zaplecze organizacyjne, aby móc wpływać na działalność Dumy, a także myśleć o zwycięstwie w kolejnych wyborach prezydenckich. Efektem jednej z takich prób było utworzenie w lipcu 1992 r. Forum Sił Demokratycznych (Forum diemokraticzeskich sił - FDS). Inicjatorami jego powołania byli tzw. pragmatycy związani ze strukturami ówczesnej władzy państwowej, w tym np. J. Gajdar oraz A. Czubajs. Już w listopadzie FDS przemianowało się na „Demokratyczny Wybór” („Diemokraticzeskij wybor"). Jego oficjalnym celem stało się działanie na rzecz społecznego poparcia dla kursu reform realizowanych przez władze państwowe. W lipcu 1993 utworzono komitet organizacyjny partii politycznej - ruchu „Wybór Rosji” („Wybor Rossii”). Oficjalne jej utworzenie miało miejsce dopiero po wydarzeniach sierpniowych w Moskwie. 
W utworzeniu „Wyboru Rosji” wzięli udział „demokraci” z różnych ugrupowań. Do kierownictwa tej formacji weszli m.in. liderzy „Demokratycznej Rosji”. Podejmowane przez J. Gajdara wysiłki zmierzające do przekształcenia ugrupowania w nowoczesną, rozbudowaną i zcentralizowaną partię napotykały na zdecydowany opór. W ugrupowaniu znalazło się wielu działaczy, którzy opowiadali się za jak najmniejszym sformalizowaniem jego struktur i działań. Tym samym przeciwstawiali się próbom narzucenia partii kierownictwa i programu oraz zasad działania przez administrację rządową. W efekcie do „Wyboru Rosji” nie weszły RPRF ani SDPR. Kierownictwa obydwu partii oficjalnie zaangażowały się w działalność „Jabłoka”, które pretendowało do roli „,demokratycznej alternatywy" w stosunku do ówczesnej władzy.

W rzeczywistości „Jabłoko” wcale nie było partią demokratyczną. Stanowiło raczej rodzaj partii notabli. Świadczy o tym chociażby pierwotna nazwa ugrupowania: blok ,Jawliński - Bołdyriew - Łukin”. Pierwszoplanową rolę odgrywał w nim G. Jawlińskij. To on we wrześniu 1993 r. w wyborach do Dumy Państwowej ustalił partyjną listę kandydatów, na której znaleźli się w przeważającej liczbie jego najbliżsi współpracownicy. W skład „Jabłoka” weszło kilka innych ugrupowań obecnych już wcześniej na rosyjskiej scenie politycznej. Ugrupowania te nie były w stanie samodzielnie spełnić wymogów stawianych komitetom wyborczym przy rejestracji list kandydatów w wyborach parlamentarnych. Wchodząc w skład wspólnego bloku wyborczego znacznie zwiększały swoje szanse na sukces wyborczy i oddalały niebezpieczeństwo odejścia ze sceny politycznej. Rezygnowały jednak z części swojej tożsamości na rzecz wspólnego programu.

Blok Wyborczy „Jawlińskij - Bołdyriew - Łukin” cieszył się znacznym poparciem w środowiskach inteligencji i menadżerów. „Jabłoko” stanowiło demokratyczną formację polityczną skupiającą najbardziej dojrzałą i ofensywnie nastawioną grupę reformatorów. W sensie programowym ugrupowanie opowiadało się za stopniowym i rozważnym, ale konsekwentnym wprowadzaniem reform politycznych i rynkowych. Stanowiło konstruktywną opozycję wobec administracji B. Jelcyna.

Tworzenie większych bloków politycznych, takich jak „Jabłoko” czy „Wybór Rosji” prowadziło do konsolidacji sceny politycznej i najprawdopodobniej uchroniło ugrupowania „demokratyczne” od odejścia w niebyt polityczny. Proces ten jednak nie miał naturalnego charakteru. Nie był on spowodowany narastającą zbieżnością programową i organizacyjną. Występowały tu zgoła inne przyczyny. W przypadku „Wyboru Rosji” konso- 
lidacja następowała w oparciu o wyraźne zaangażowanie się w procesy zjednoczeniowe aparatu państwowego oraz silnych grup wpływu politycznego. W przypadku „Jabłoka” była to charyzma przywódcy ugrupowania. W praktyce dosyć szybko okazało się, że ani jeden, ani drugi czynnik nie były tak silnym stabilizatorem, aby uchronić porozumienia wyborcze od powtórnej atomizacji. Było to szczególnie widoczne w przypadku „Wyboru Rosji”, chociaż w pewnej mierze nie ominęło również „Jabłoka”.

Warto w tym miejscu zwrócić uwagę na występującą specyfikę rosyjskiej sceny politycznej. Pewnego rodzaju tradycją ugrupowań demokratycznych była daleko idąca destabilizacja wewnętrzna. Dotyczyła ona zarówno struktury organizacyjnej, przywództwa politycznego, jak i programów politycznych. Prowadziło to często do przedziwnych sytuacji. W okresie kampanii wyborczej w 1993 r. niektóre regionalne struktury poszczególnych partii politycznych zawierały sojusze i wchodziły w skład przeciwstawnych bloków wyborczych. Tak też było w przypadku RPRF i SDPR, których członkowie, a nawet całe organizacje terenowe, wstępowały do „Wyboru Rosji” chociaż obydwie partie formalnie stowarzyszyły się z „Jabłokiem”. Tego typu zachowania były, jak to określił G. Gołosow, przysłowiowym gwoździem do trumny „ruchów demokratycznych” w Rosji ${ }^{29}$.

Wrześniowo-październikowy kryzys polityczny w 1993 r. w Rosji wywarł potężny wpływ na jej system partyjny. Działalność niektórych partii np. FNS, RKRP, KPRF oraz partii A. Ruckoja została zakazana. W znacznej większości przypadków zakaz ten był chwilowy. Niekiedy jednak władze państwowe nie wyraziły zgody na wznowienie działalności konkretnych partii. Przywódcy niektórych ugrupowań politycznych zostali aresztowani. Dotyczyło to tych osób, które zaangażowały się czynnie po stronie parlamentu. „Partia władzy” znajdowała się wówczas na etapie organizowania się. Jej struktury, poza centralnymi, jeszcze nie istniały. Praktycznie wszystkie dotychczas działające ugrupowania polityczne znajdowały się w głębokim kryzysie. W takich warunkach przystąpiono do kampanii wyborczej i wyborów parlamentarnych w 1993 r. Walka polityczna przebiegała w sytuacji dużej dezintegracji sceny politycznej. Nie dość, iż większość aktorów występujących na tej scenie nie było należycie przygotowanych do swej roli, to jeszcze każdy grał inną sztukę, nie bacząc na pozostałych. Było to efektem braku ukształtowanego systemu partyjnego.

29 G. W. Gołosow, Proischożdienije sowriemiennych rossijskich politiczeskich..., op. cit., s. 100 . 


\section{Summary}

The party system is only shaping in contemporary Russia. The process commenced in 1990 when the change of the Constitution provided for free establishment of political parties in Russia. Banning of the Communist Party of the Soviet Union resulted in numerous new parties emerging with an ambition of becoming a dominating party in Russian politics. These attempts failed to succeed. Dynamic development of political organizations was related to democratic election procedures. Quantitative development was not conducive for the stability of political stage. Dispersed, insignificant political parties were not an efficient instrument of political influence. There were numerous attempts to consolidate the groups of similar political platforms, yet they did not generated expected results. Even the most important political campaigns related to parliamentary or presidential elections were unable to consolidate political parties in Russia.

The absence of a clear parliamentary majority as well as dispersion and a clearly confrontational policy of the parties was conducive for increasingly stronger presidential authority. The lack of a clear party system resulted in a failed attempt to restore the former political system.

In 1992-1993 attempts were made to provide political support for the so-called reformatory government. They failed to generate any permanent organizational solutions. Political elite was unable to consolidate either around the strategic objectives or around their leaders. In the initial period of democracy shaping in Russia a party system did not provide any support for this democracy. It was rather its caricature. 